\title{
教育講演
}

\section{神経系の電気生理学的検査 一体性感覚誘発電位（SEP）を中心に一}

\author{
木村彰男*
}

\section{はじめに}

従来, 筋電図を中心とする電気生理学的検查 の扱う範囲は, 末梢神経と筋肉を中心とした運 動単位（motor unit）に限られていた。しかし ながら, 近年の医用電子工学の進歩は目を見張 るばかりで, $\mu \mathrm{V}$ 単位の電位変化もいとも簡単に 記録できるようになり，臨床応用がさかんにな ってきている。すなわち平均加算法の導入によ り, 神経伝導検查が運動神経から知覚神経へと 拡大されていったばかりでなく, 最近では末梢 神経から中枢神経へとその応用が進み, 大脳誘 発電位の導出も日常検査として行うことが可能 となってきている.

今回は, 筋電図および神経伝導検査について, $\mathrm{H}$ 波・F波，Blink reflex を含めて概説すると ともに, 大脳誘発電位に関しては特に体性感覚 誘発電位について解説したい。

*慶応義塾大学月が瀬リハビリテーションセンター

\section{I 筋電図検査 ${ }^{1) ~ 3)}$}

(Electromyography : EMG)

用いる電極の種類により，表面筋電図と針筋 電図とに分かれる.運動力学の解析のためには, 表面筋電図を用いた動作筋電図が重要であるが, 末梢神経および筋肉疾患の診断に役立つ，いわ ゆる生理機能検査としての筋電図という場合に は，通常針筋電図のことを指す，以下，針筋電 図について述べるが，特に断らない限り，筋電 図はすなわち針筋電図を意味することとする。

筋電図検査は，一言で言えば運動単位の異常 の有無を，細胞膜に生ずる電位変化により測定 する検査ということができる，運動単位とは， 前角細胞, 軸索または運動神経線維, 神経筋接 合部, 筋肉より構成され, この活動電位が筋電 図として記録されるわけである。すなわち，筋 電図は下位運動ニューロンと筋肉の検査であり, 中枢神経疾患にたいしては直接の診断価值はな い.また筋電図検查単独で得られる情報は限ら 
れており，その検査結果は次に述べる神経伝導 検査などと併せて総合的に判断されるべきもの である。さらに筋電図を含む電気診断は，あく まで補助診断の一つであり，それに先立っての 病歴聴取や神経学的現症が大事であることを常 に銘記する必要がある。

実際の筋電図検查は, 安静時と随意収縮時の 二段階に分けて行なう. 以下，正常と異常の場 合の筋電図所見について述べる。

1 ）正常筋電図

安静時の筋電図は, 運動単位に異常のない場 合にはいわゆる電気的沈黙 (electrical silence) の状態で, 何ら電位変化を観察することはでき ない.

個々の運動単位の活動電位（motor unit action potential：MUP)は, 筋の微小収縮時に 観察するわけであるが，正常の MUP は図 1 に 示すように周期性のある二ないし三相性の波で, $0.2 \sim 2.0 \mathrm{mV}$ の振幅をもち，その持続時間は 4〜12msec である.

筋の最大収縮時には, 運動単位の発射頻度が 増すとともに, 複数の運動単位が活動するため MUP は互いに重なりあうようになる.この状態 を干涉波（interference pattern）と呼ぶが，正 常の場合は干涉波で基線が見えなくなる。

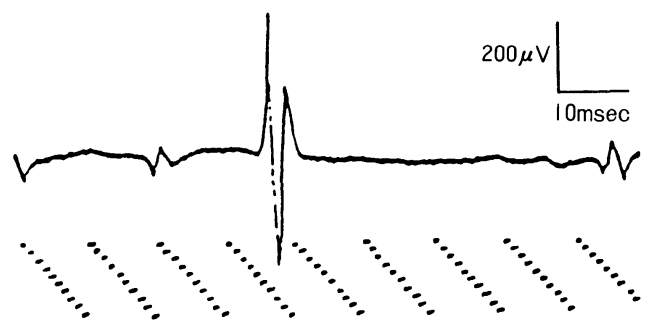

図 1 正常の運動単位活動電位

振幅 $0.5 \mathrm{mV}$ ，接続時間 $6 \mathrm{msec} の$ 三相性の MUPである。

\section{2 ）異常筋電図}

安静時の異常波形の検出は, 一連の筋電図検 査のなかで最も大切な部分を占める．以前は収 縮時の MUP の変化が重要視されたが，これは 収縮の状態や針電極の位置により影響を受けや すいので，今では安静時の検查に主体が置かれ るようになっている．正常安静時における電気 的沈黙にたいして，末梢神経，筋肉などの異常 にさいしては，筋電図上安静時に自発放電すな わち線維自発電位（fibrillation potential）や陽 性鋭波（positive sharp wave）が観察される。 これらは脱神経線維に出現しやすいことから， “脱神経電位 (denervation potential)”と呼ば れ，それぞれ特徴的な波形を示すとともに，独 特の音をスピーカーから生ずる。ところで安静 時自発電位は，末梢神経損傷の場合，その出現 までに受傷後約 3 週間かかるので，筋電図検査 の施行時期には充分な配慮が必要である。

その他の安静時自発電位として線維束電位 （fasciculation potential）があるが，これは肉 眼的に観察される筋攣縮と同じものである．前 角細胞疾患や神経根刺激時に出現するが，生理 的なものもあるのでこれのみで異常と判定する ことは危険である。

随意収縮時における異常筋電図は，すなわち MUP の変化であり,下位運動ニューロンの障害 では神経原性の MUP が，筋肉疾患では筋原性 の MUP が観察されるようになる．前者は振幅 の大きい持続時間の長い波で, 後者は振幅の小 さい持続時間の短い波であるが，いずれも多相 性となる。下位運動ニューロンの障害の場合に は, 最大収縮時における干涉波の減少もみられ る.

正常および異常筋電図の所見を疾患別にまと めると表 1 に示すようになる。 
表 1 正常および異常筋電図

\begin{tabular}{|c|c|c|c|c|}
\hline & 正 & 前角細胞疾患 & 末梢神経障害 & 筋 疾 患 \\
\hline \multicolumn{5}{|l|}{ 安静時 } \\
\hline 刺入時活動（Ins. Act.） & 20msec未満 & 延長 & 延長 & 種々 \\
\hline $\begin{array}{c}\text { 線維自発電位（Fib.）または } \\
\text { 陽性鋭波（P-w.） }\end{array}$ & 無 & 有 & 有 & まれ \\
\hline 線維束電位（Fasc.） & 無 & 有 & まれ & 無 \\
\hline \multicolumn{5}{|l|}{ 随意収縮時 } \\
\hline 振幅（Amp.） & $0.2 \sim 2.0 \mathrm{mV}$ & $2.0 \sim 5.0 \mathrm{mV}$ & $0.3 \sim 3.0 \mathrm{mV}$ & $0.1 \sim 0.3 \mathrm{mV}$ \\
\hline 持続時間（Duration） & $4 \sim 12 \mathrm{msec}$ & $5 \sim 20 \mathrm{msec}$ & $3 \sim 15 \mathrm{msec}$ & $\mathrm{I} \sim 3 \mathrm{msec}$ \\
\hline 多相波（Polys.） & $\sim$ & $\uparrow$ & $\uparrow$ & $\uparrow$ \\
\hline 干涉波（I nt. Patt.) & $\sim$ & $\downarrow$ & $\downarrow$ & $\sim$ \\
\hline
\end{tabular}

\section{II 神経伝導検査 ${ }^{1)-3)}$ \\ (Nerve conduction study)}

神経伝導検査は, 主として末梢神経の障害を 調べる検査で，通常筋電図検査と同時に施行さ れるが, 筋電図に比べ神経の損傷状態をある程 度定量的に測定できる，という利点を有してい る。運動神経伝導検査と知覚神経伝導検査に分 けられるが，いずれも対象となるのは主として 直径の大きい $\mathrm{A}$ 線維に属する有髄神経線維であ る.

神経伝導検査は, 以下に述べる神経伝導速度 や潜時を指標として, 外傷による神経損傷のほ か, 中毒・代謝障害によるニューロパチー, 末 梢神経がその走行の途中で圧迫を受けるエント ラップメントなどで必要不可欠の情報をもたら し，末梢神経の診断に重要な役割を果たしてい る.

\section{1) 運動神経伝導検查}

運動神経伝導検査は, 未梢神経の一部を電気 刺激して，その支配筋における誘発反応電位す なわち $\mathrm{M}$ 波を導出し,軸索以下の運動単位の異 常を調べる検査である，検査の指標としては，
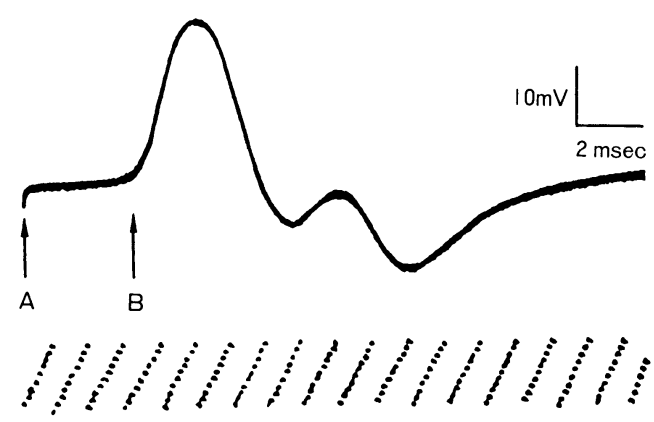

\section{図 2 運動神経伝導検査}

手関節部正中神経刺激の際の短母指外転筋よりの $\mathrm{M}$ 波 を示す、A-B間がすなわち潜時である。

運動神経伝導速度 (MCV), 潜時 (latency), $\mathrm{M}$ 波の波形・振幅・持続時間などが用いられる.

図 2 に示すように，末梢神経を刺激した際の アーチファクトから M 波の立ち上がりまでの伝 導時間がすなわち潜時で, これは刺激が末梢神 経から神経筋接合部を経て筋線維へと伝わり, 筋収縮を起こすまでに要する時間である，同一 神経の 2 カ所, 例えば正中神経では肘関節部と 手関節部の 2 力所で刺激した際のおのおのの潜 時を測定し, その差を求めると前腕部での末梢 神経のみの伝導に要する時間がわかる。この伝 導時間と, 2 力所の測定部位の間の距離から, 
表 2 神経伝導検査の正常值

\begin{tabular}{|c|c|c|c|}
\hline \multicolumn{4}{|l|}{ a）運動神経 } \\
\hline \multirow{2}{*}{ 神 経 名 } & \multirow{2}{*}{$\begin{array}{c}\text { 神経伝導速度 } \\
(\mathrm{m} / \mathrm{sec})\end{array}$} & \multicolumn{2}{|c|}{ 遠位潜時 } \\
\hline & & 時間 $(\mathrm{msec})$ & 距離 $(\mathrm{cm})$ \\
\hline 正中神経 (median n.) & $57.4 \pm 4.0$ & $3.79 \pm 0.30$ & 7 \\
\hline 尺骨神経（ulnar n.） & $61.4 \pm 5.2$ & $2.84 \pm 0.30$ & 7 \\
\hline 腓骨神経（peroneal n.） & $48.3 \pm 3.9^{*}$ & & \\
\hline 脛骨神経（tibial n.） & $48.5 \pm 3.6^{*}$ & & \\
\hline \multicolumn{4}{|l|}{ b) 知覚神経 } \\
\hline \multirow{2}{*}{ 神 経 名 } & \multirow{2}{*}{$\begin{array}{c}\text { 神経伝導速度 } \\
(\mathrm{m} / \mathrm{sec})\end{array}$} & \multicolumn{2}{|c|}{ 遠位潜時 } \\
\hline & & 時間 (msec) & 距離 $(\mathrm{cm})$ \\
\hline 正中神経 (median n.) & $56.4 \pm 4.7$ & $2.48 \pm 0.21$ & 14 \\
\hline 尺骨神経（ulnar n.） & $56.9 \pm 6.2$ & $2.46 \pm 0.27$ & 14 \\
\hline 橈骨神経（radial n.） & $55.5 \pm 6.0$ & $2.52 \pm 0.27$ & 14 \\
\hline 腓腹神経（sural n.） & $48.3 \pm 5.3^{*}$ & & \\
\hline
\end{tabular}

*文献2)より引用

同部の神経伝導速度つまり $\mathrm{MCV}$ が算出できる。 この方法で，上下肢の主要な神経である正中・ 尺骨神経，腓骨・脛骨神経の MCV の測定は簡 単に行える，顔面神経，腋窩神経のように神経 走行上の 2 力所での刺激が難しい場合には $\mathrm{MCV}$ の測定は不能で, 潜時を指標として左右差を比 較することなどにより診断の助けとする．表 2 - $\mathrm{a}$ に各神経の MCV の值と潜時をまとめておく.

$\mathrm{M}$ 波の波形・振幅なども重要で，正常では二 ないし三相性であるが，末梢神経損傷などでは 神経線維の伝導速度にバラツキが生じ多相性と なり，拡幅も変化する。

\section{2 ) 知覚神経伝導検査}

運動神経伝導検査が末梢神経を刺激して筋肉 よりの $\mathrm{M}$ 波を記録するのに対して, 知覚神経伝 導検查では知覚神経を刺激して同じ神経のほか の部位より活動電位を導出する。刺激電極と記 録電極の間には，神経筋接合部・筋線維などを 含まないため, 両電極間の距離を直接潜時で割 ることにより知覚神経伝導速度 $(\mathrm{SCV})$ の算出
が可能で, 2 力所での測定は普通必要としない. 知覚神経の末梢部を刺激して中枢部より記録 する順行性測定法 (orthodromic technique) と, その逆に刺激と記録を行う逆行性測定法（antidromic technique）とがあるが，どちらの方法 を用いても SCV に差はみられない.逆行性測定 法では大きな振幅をもつ活動電位が得られる反 面, $\mathrm{M}$ 波の混入が起こるというように一長一短 があり, 日常臨床の場では必要に応じて使い分 けるべきである。

上肢では正中・尺骨神経および橈骨神経が知 覚神経伝導検査の対象となり，順行性測定法の 場合，通常示指や小指などの指に巻いた環状電 極を刺激として用い，手関節部の神経上の皮膚 より知覚神経活動電位（SNAP）を記録する。 検查機器の進歩により簡単に SNAP が導出でき るようになった反面，あまりに器械の精度が高 まったために,近接する他神経からの SNAP の 混入 (contamination) というょうな問題も生じ るようになっており，検査に際しては充分な注 意が必要である ${ }^{4)}$. 上肢各神経のほかに, 下肢で は純粋な知覚神経である腓腹神経が，知覚神経 伝導検査の対象としてしばしば用いられる。

表 $2-\mathrm{b}$ に知覚神経伝導検查の正常値をまとめ ておく

\section{III $\mathrm{H}$ 波と F 波 ${ }^{2), 3)}$ (H-reflex \& F-wave)}

一般の神経伝導検査では，運動神経・知覚神 経いずれの検査でも，上肢では肘関節以下，下 肢では膝関節以下の遠位部の末梢神経が対象と なる。これに対し，運動・知覚両神経が同時に 関与する反射弓の評価やあるいはより中枢部の 末梢神経の伝導状態を検查する場合に用いられ るのが, $\mathrm{H}$ 波や $\mathrm{F}$ 波の計測である.

$\mathrm{H}$ 波は $\mathrm{H}$ 反射とも呼ばれ, 1918年に Hoffman 
により初めて記載され，その頭文字をとってこ のように名付けられている. $\mathrm{H}$ 波は筋の伸張反 射である単シナプス反射を, 電気的刺激により 引き起こし記録したもので, 通常上肢では出現 しにくく下肢で記録しやすい.

脛骨神経を膝窩部で電気刺激して，ヒラメ筋 より $\mathrm{H}$ 波を導出する方法が一般に用いられる。 電気刺激により求心性の I a 線維が興奮し,この インパルスが脊髄へ上行し $\alpha$ 運動線維を興奮さ せ, 結果として筋肉の収縮が起こるのが $\mathrm{H}$ 波の メカニズムであるが, 上の方法では正常の場合 約 $30 \mathrm{msec}$ の潜時で $\mathrm{H}$ 波が記録できる. $\alpha$ 線維の 逆行性の刺激伝導の関係で, 強く刺激しすぎる と $\mathrm{H}$ 波は消失してしまい, 普通最大下刺激が用 いられる。

$\mathrm{H}$ 波は $\mathrm{M}$ 波との比較をしたり,その回復曲線 を求めることにより痙性麻痖の評価に利用され るが, 2 力所で測定する事により SCV の算出に も応用できる。

一方 $\mathrm{F}$ 波は，1950年に Magladeryと McDougalにより記述され，現在ではおおむね 運動線維を逆行性に伝導するインパルスによる 一部の $\alpha$ 運動ニューロンの興奮に基づく，と考 えられている，H波にたいし F 波は，上下肢筋 のいずれからも導出が可能で，また刺激として は最大上刺激が必要とされる。

$\mathrm{F}$ 波は通常の運動神経伝導検查では測定でき ない, 泰髄に近い末梢神経の伝導性を検查する のに非常に有効で, 各種疾患に応用されている. $\mathrm{F}$ 波による伝導速度（FWCV）のほか， $\mathrm{M}$ 波の 潜時と比較した F-ratio と呼ばれる指標が診断に 用いられる。

\section{IV 瞬目反射 ${ }^{2)}$ (Blink reflex)}

電気生理学的方法による反射弓の評価は, 脳
幹部では瞬目反射として臨床応用されている. これは神経学的検査で行う結膜反射を電気刺激 により引き起こし，眼輪筋よりその誘発反応を 記録するもので，具体的には求心性の刺激を三 叉神経の眼窩上神経 (supraorbital nerve) 枝に 与え，その遠心性反応を顔面神経支配の下眼輪 筋から記録する。そして潜時と波形から反射弓 の病態を検索するわけであるが，刺激と同側と 反対側の両方の誘発反応が評価に用いられる.

正常の場合, 刺激と同側からは約 $10 \mathrm{msec}$ の潜 時をもつ第 1 波 $\left(\mathrm{R}_{1}\right)$ と, 約 $30 \mathrm{msec}$ の潜時をも つ第 2 波 $\left(\mathrm{R}_{2}\right)$ とが記録されるが，刺激反対側 からは $\mathrm{R}_{2}$ が記録されるのみである. $\mathrm{R}_{1}$ は橋を介 しての三叉神経から顔面神経への反射弓， $\mathrm{R}_{2}$ は 延髄を通しての刺激同側のみでなく反対側へも 伝わる反射弓の反応と考えられている。

瞬目反射は, 顔面神経麻痺, 多発性神経炎に 代表される末梢神経障害や聴神経腫, 多発性硬 化症のような脳幹部の異常を呈する疾患の診断 に用いられている。

\section{$\mathrm{V}$ 体性感覚誘発電位 ${ }^{2), 5), 6)}$}

(Somatosensory evoked potentials : SEP)

大脳誘発電位は, 感覚を客観的に捕らえる手 段として最近大いに注目されている，大脳誘発 電位には聴性脳幹誘発電位, 視覚誘発電位など 幾つかのものがあるが，ここでは末梢神経を刺 激して大脸皮質感覚野から誘発電位を導出する 体性感覚誘発電位 (SEP) について解説したい。

(1) 基本的知識

SEP は末梢神経から春髄後索を経て, 更に内 側毛帯から視床を通り大脳皮質感覚野へ投射す る電気現象を反映する，と考えられている。こ れは即ち振動覚, 位置賞の伝導路で, その臨床 
所見との相関が注目されている。

上肢では正中・尺骨神経, 下肢では腓骨・脛 骨神経など種々の末梢神経刺激での SEP が報告 されている，記録の容易さなどの点から，正中 神経刺激が一般的に広く行われている。上肢神 経刺激の場合, 刺激から $20 \mathrm{msec}$ 以内に生ずる電 位を扱う短潜時 SEP (short latency somatosensory evoked potential）と，それ以降の電位を 問題にする長潜時 SEP (long latency somatosensory evoked potential）とに分けら れる.長潜時 SEP が刺激後どのくらいの潜時ま での電位を扱うかは，はっきりした定説がない

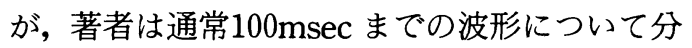
析している。

短潜時 SEP は, far field potensials の考えの 導入以来急速に発展を遂げ, 各成分についても ほぼその発生源が解明されている.何故 far field potensials が発生するかについては, 現在議論の まっ最中であるが, 病変の部位決定に役立つも のとして臨床面での期待は大きい.

長潜時 SEP は, 後期成分の再現性に問題があ り，また各波形についても不明な点も多いが， 脳血管障害を中心とした大脳半球，視床などの 病変の分析には不可欠で, 今後の研究が待たれ る.

（2）記録方法

\section{(1)刺激}

通常は，安定した刺激が得られるために $0.1 \sim 0.2 \mathrm{msec}$ の矩形波による電気刺激が用いら れ，その強度は運動閾值の $1.3 \sim 1.5$ 倍, 感覚闘 值の 3 倍が適当とされている，具体的には，正 中神経では手関節で刺激し母指球筋が軽く収縮 する程度の強さである.刺激頻度は $4 \mathrm{cps}$ 前後が 用いられ，短潜時 SEP では500〜1000回以上の 加算が必要であるが, 長潜時 SEP では100〜200
回でも記録が可能である，従来，右ないし左の 片側刺激が行われているが, 最近では左右両側 同時刺激が併せて用いられるようになってきて いる.これにより左右大脳半球の SEP の対称性 を比較することができるので，著者も先ずスク リーニング的に両側同時刺激を行うことを原則 としている.

(2)記録

記録電極としては，脳波用の円板電極を用い るが, 得られる波形が $\mu \mathrm{V}$ 単位の小さいもので あるため, 電極抵抗を低くすることが極めて大 事で， $5 \mathrm{k} \Omega$ 以下にする必要がある. 記録電極は, 頭皮上では国際10-20電極配置法に従い置かれ るが, 上肢神経刺激では普通 $\mathrm{C}_{3}$ ないし $\mathrm{C}_{4}$ が用い られる.しかしながら，SEP の各波形は頭皮上 で複雑な分布を示すため，単一の誘導ではなく 同時に幾つかの部位から記録することが必要で ある。著者は頭皮上 6 チャンネルに，頸椎およ び上腕神経叢からの誘導を加え, 通常 8 チャン ネル同時記録を行っている(図 3 ). その際, 基 準電極としては両側耳㭝を用いている。

またSEP の波形はフィルターの設定により著 しく影響を受けるため, フィルターの選択も重

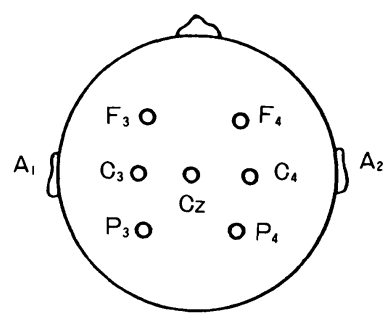

10-20 Electrode System \begin{tabular}{l} 
(1) $F_{3}-A_{1}+A_{2}$ \\
(2) $F_{4}-A_{1}+A_{2}$ \\
(3) $C_{3}-A_{1}+A_{2}$ \\
(4) $C_{4}-A_{1}+A_{2}$ \\
(5) $P_{3}-A_{1}+A_{2}$ \\
(6) $P_{4}-A_{1}+A_{2}$ \\
\hline (7) $C_{2}$ or $E r b$ \\
$-A_{1}+A_{2}$
\end{tabular}

(8) $\mathrm{CV}_{7}-\mathrm{A}_{1}+\mathrm{A}_{2}$
図 38 チャンネル同時記録の際のモンタージュ (7) チャンネルは両側刺激では $\mathrm{Cz}$ よりの, 片側刺激 ではErb点よりの導出としている. 
要な問題となる，詳細は省くが著者は, 短潜時 $\mathrm{SEP}$ では $15 \mathrm{~Hz} \sim 3 \mathrm{kHz}$ を, 長潜時 SEP では $5 \mathrm{~Hz}$ 〜 $1 \mathrm{kHz}$ を用いている.

（3）命名法と正常波形

SEP の各波形の命名については幾つかの方法 があり, 多少の混乱を招いているが, 最近では 各波形の極性と共に潜時をつけて呼ぶ方法が広 く用いられている. $\mathrm{P}_{9}, \mathrm{~N}_{19}, \mathrm{~N}_{32}$ というように 用いるが, SEP の各成分の潜時は人により多少 の違いがあり，例えば同じ $\mathrm{N}_{19}$ でも 17 ないし 18 $\mathrm{msec}$ 付近に生ずることがある.そのため潜時に 違いがあっても, 同じ成分をさしているときに は平均值を用い $\mathrm{N}_{19}$ と呼ぶことにしている。

さて SEP の波形は, 報告者により基準電極の 選び方・フィルターの設定条件などに違いがあ るため，単純に比較することはできない. 近年, 記録の標準化が提唱されているが，まだまだ議 論の余地があり, 統一には時間がかかりそうで ある。

以下に, 最も一般的に行われている正中神経 刺激の際の正常波形について述べる.

\section{(1)短潜時 SEP}

両側耳梁を基準電極として, $\mathrm{C}_{3}$ ないし $\mathrm{C}_{4}$ より SEP を記録すると, 13〜 $14 \mathrm{msec}$ に頂点潜時を持 つ陽性波と $19 \mathrm{msec}$ 付近に頂点潜時を持つ陰性 波が記録できる. 同じ $\mathrm{C}_{3}, \mathrm{C}_{4}$ からの記録でも膝 に基準電極を置いた場合には，9および $11 \mathrm{msec}$ にさらに 2 つ陽性波が記録できる。一方，頸 椎からの記録では $9,11,13$ および $14 \mathrm{msec} に$ 頂点潜時を持つ波が記録できるが，これらは頭 皮上からの記録とは逆に陰性波となる（図 4).

このように誘導法により極性の違いはあるも のの，ほほ同じ潜時をもつ 4 つの波が認められ る. 即ち頭皮上よりの記録では, $\mathrm{P}_{9}, \mathrm{P}_{11}, \mathrm{P}_{13}$, $\mathrm{P}_{14}$, 頸椎よりの記録では $\mathrm{N}_{9}, \mathrm{~N}_{11}, \mathrm{~N}_{13}, \mathrm{~N}_{14}$ と
呼ばれる波である。

各波形の発生源であるが, $\mathrm{P}_{9}\left(\mathrm{~N}_{9}\right)$ は図 4 か らわかるようにほほ Erb 点からの導出電位に一 致する. そのため $\mathrm{P}_{9}$ も腕神経叢起源と考えられ ているが, 正確には Erb 点の電位よりごく僅か に先んじて出現しており, Yamada らは, 腕神 経叢よりやや末梢から発生するとしている。

$\mathrm{P}_{11}\left(\mathrm{~N}_{11}\right)$ については, 手関節から第 7 頸椎 までの末梢神経の伝導時間が丁度10ないし11 msec であることより, 神経根の頸髄への入口部 がその発生源と考えられているが, 頸髄後角, 頸髄後索とする説もあり，はっきり同定されて はいない.

$\mathrm{P}_{13}\left(\mathrm{~N}_{13}\right)$ は, 頸髄の ascending volley とす る説のほか, 楔状核などがその発生源とされて おり，また $\mathrm{P}_{14}\left(\mathrm{~N}_{14}\right)$ は，以前は視床と考えら れていたが, 最近では内側毛帯が有力視されて いる、いずれにしろ，これらにもまだ定説はな く今後の研究課題といえる.

このように末梢神経や頸髄で生じた電位が, 容積伝導により頭皮上に広く分布し, いわゆる

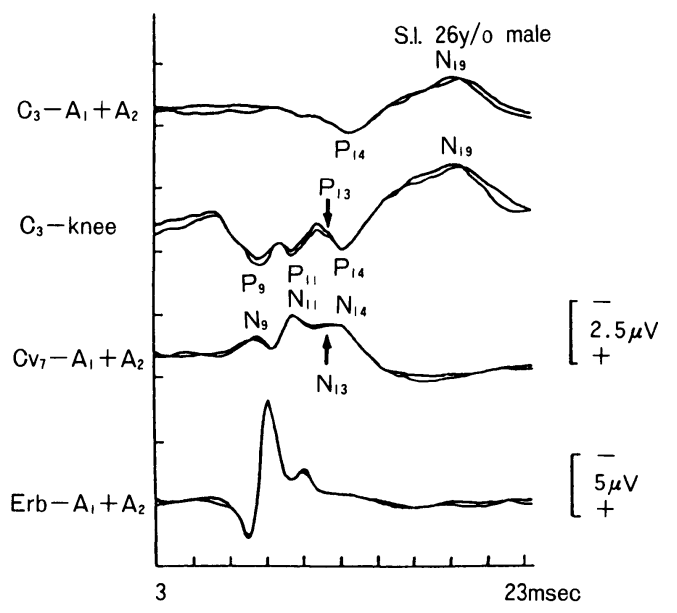

図4 右正中神経刺激の際の短潜時 SEP の正常波形 
far field potentials として記録されたものが, $\mathrm{P}_{9}, \mathrm{P}_{11}, \mathrm{P}_{13}, \mathrm{P}_{14}$ であるが，なぜこれらが発生 するかについては未だ明らかでない. 解剖学的 な要因と結びつけて神経を取り巻く容積伝導体 の急激な変化を原因とする説，神経の走行に関 連づけて, 神経の複雑な分枝をその発生原因と する説などがあり, far field potentials の解明 が現在の短潜時 SEP の研究のトピックスとなっ ている。

頭皮上で，これらの far field potentials に続 いて記録される19ないし20msec に頂点潜時をも つ陰性波については次の長潜時 SEP の項で詳し く述べる.

(2)長潜時 SEP

図 5 に示すように, 正常では $\mathrm{C}_{3}$ ないし $\mathrm{C}_{4}$ より の導出で, 3 つの陽性波, $\mathrm{P}_{14}, \mathrm{P}_{23}, \mathrm{P}_{40}$, と 3 つの陰性波, $\mathrm{N}_{19}, \mathrm{~N}_{32}, \mathrm{~N}_{60}$ が記録できる. $\mathrm{P}_{14}$ は短潜時 SEP で述べたように, 視床ないし内側 毛帯を発生源とする far field potential と考えら れている。

$\mathrm{N}_{19}$ は最初の陰性波で, 特殊視床皮質投射系な いしは皮質感覚領野より発生する電位と思われ る.興味あることは, この波が頭皮上の導出部 位によりわずかながら潜時が異なってくること

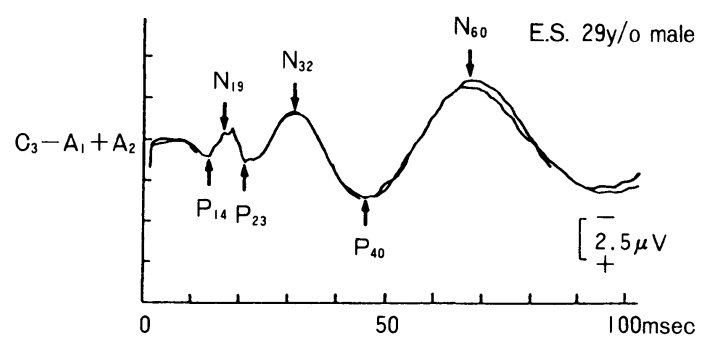

図 5 長潜時 SEP の正常波形

右正中神経刺激における $C_{3}$ よりの導出波形である。
である (図 6 )。すなわち, 刺激反対側の頭頂部 と同様に, 前頭部, 後頭部からもほほ似た波形 が得られるが, $\mathrm{C}_{3}$ ないし $\mathrm{C}_{4}$ で $\mathrm{N}_{19}$ を示す陰性波 は, 前頭部では $\mathrm{N}_{17}$, 後頭部では $\mathrm{N}_{20}$ となる.さ らに多チャンネル同時記録により詳しく観察す ると,頭頂部では $\mathrm{N}_{19}$ の前後に小さな notch がみ られ, 各々 $\mathrm{N}_{17}, \mathrm{~N}_{20}$ と一致する. $\mathrm{N}_{17}$ は刺激と同 側の頭皮上より広く導出されるが, $\mathrm{N}_{19}$ は刺激反 対側の感覚領野に限局して出現する。このよう に一見同じ様に見える波でも，導出部位により 違う性格をもつ波であることが確認されたわけ で， $\mathrm{N}_{17}$ は皮質下， $\mathrm{N}_{19}$ は皮質よりの電位である と推察できる. $\mathrm{N}_{17}$ は視床付近がその発生源と考 えられている. $\mathrm{N}_{20}$ も $\mathrm{N}_{19}$ と同様の性格を持つ波 で，これらの起源については現在多くの議論が なされている.

頭頂部での $\mathrm{N}_{19}$ に続いて記録される波について は，残念ながら余り解明されていない。これら は $\mathrm{N}_{19}$ 以前の波と異なり，人により個体差があり， 多少不安定な性質をもつ.特に $\mathrm{N}_{60}$ は睡眠による 影響を受け易く，また皮質上に広く分布するこ とにより, $N_{19}$ とは明らかに違う性格を持つ波で あることがわかる．多数のシナップスをもつ非 特殊系の経路が関与していると思われるが, 詳

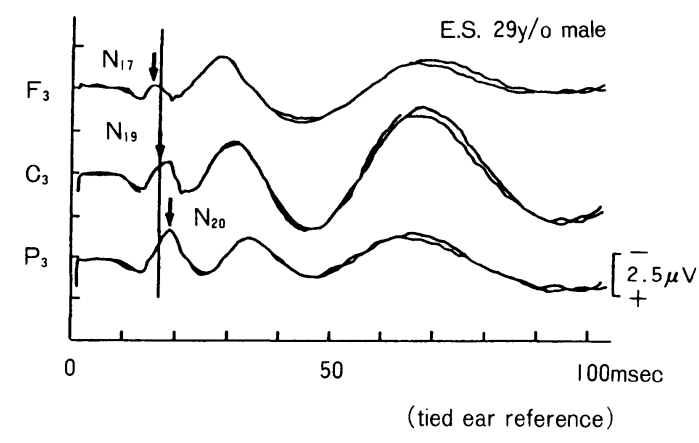

図 6 正常人における $N_{17}, N_{19}, N_{20}$ の頭皮上分布 
細は未だ不明である。

(4) 正常値とその解釈

各報告者により, 電極の置き方, フィルター の設定条件など種々の条件が違うため, 一概に その正常值を決めることは難しい.また身長お よび上肢の長さにより, SEP の潜時も多少違つ てくるので注意しなければならない.

表 3,4 は正中神経刺激の際の SEP の各成分 の潜時の正常值であるが，その絶対值は上に述 べたような理由で個人差があるので，左右の同 じ波の潜時の差を求めて比較するのも一つの方 法である。

通常は潜時を中心に正常值が述べられ，振幅 について正常値が論じられることは少ない，潜 時に比べ振幅の再現性が低いためで，振幅の違 いのみで正常, 異常を判断するのは現在までの ところ危険である。

(5) SEP の臨床応用

\section{(1)末梢神経障害}

通常の末梢神経伝導検査は，腋窩以下につい て行われ，それより中枢については測定が難し い. $\mathrm{F}$ 波， $\mathrm{H}$ 波などを用いて検査が行われてい るが，それらでは運動線維も含まれ，純粋に感 覚線維の評価はできない. SEP を用いることに より，脊髄に近い中枢部の末梢神経の感覚線維 の評価が可能となり，腕神経叢，神経根障害な どの診断に応用されている.

ところで末梢神経レベルで知覚神経活動電位 が記録できない場合でも，頭皮上から SEP が記 録できることがある.これは central amplificationの機構によるものと思われ末梢神 経伝導検査に先立っての SEP の機能回復の指標 としての有効性が示唆される。

(2)大脳半球障害

著者は脳血管障害を中心に，多チャンネル同
表 3 短潜時 SEP の正常值

\begin{tabular}{|c||c|c||c|c|}
\hline \multicolumn{1}{|c||}{} & \multicolumn{2}{c||}{ 潜 } & \multicolumn{2}{c|}{ 左右の潜時差 } \\
\cline { 2 - 5 } & 平均潜時 $(\mathrm{msec})$ & 症例数 & 平均の潜時差 $(\mathrm{msec})$ & 症例数 \\
\hline \hline$P_{9}$ & $8.3 \pm 0.6$ & 38 & $0.3 \pm 0.2$ & 19 \\
$N_{11}$ & $10.4 \pm 0.7$ & 38 & $0.2 \pm 0.2$ & 19 \\
$N_{13}$ & $12.3 \pm 0.9$ & 38 & $0.3 \pm 0.2$ & 19 \\
$N_{14}$ & $13.5 \pm 0.8$ & 38 & $0.5 \pm 0.4$ & 19 \\
$N_{19}$ & $18.0 \pm 1.0$ & 38 & $0.6 \pm 0.8$ & 19 \\
\hline
\end{tabular}

\section{表 4 長潜時 SEP の正常值}

\begin{tabular}{|c||c|c||c|c|}
\hline \multicolumn{1}{|c||}{} & \multicolumn{2}{c||}{ 潜 } & \multicolumn{2}{c|}{ 左右の洼時差 } \\
\cline { 2 - 5 } & 平均潜時 $(\mathrm{msec})$ & 症例数 & 平均の潜時差 $(\mathrm{msec})$ & 症例数 \\
\hline \hline$N_{19}$ & $18.3 \pm 1.0$ & 46 & $0.6 \pm 0.7$ & 23 \\
$P_{23}$ & $22.7 \pm 1.4$ & 46 & $1.2 \pm 0.9$ & 23 \\
$N_{32}$ & $30.2 \pm 2.2$ & 46 & $1.8 \pm 1.4$ & 23 \\
$P_{40}$ & $43.5 \pm 2.9$ & 46 & $1.6 \pm 1.3$ & 23 \\
$N_{60}$ & $70.4 \pm 10.1$ & 46 & $7.4 \pm 7.1$ & 23 \\
\hline
\end{tabular}

時記録により長潜時 SEP を記録しているが, 図 7 - $\mathrm{a}$ は CT 上中大脳動脈領域の広範な脳梗塞 を示す患者より記録したものである，麻痺は重 度で, 深部知覚・表在知覚とも著明に障害され ていた，患側刺激により，最初の陽性波に続く 陰性波のみしか記録できず，それ以降の波は消 失していた。しかもこの陰性波が頭皮上の総て の導出で同一潜時を持つことにより，これが皮 質反応でなく, 皮質下反応で生じる $\mathrm{N}_{17}$ であるこ とがわかる。

図 7-b も同じ様に, CT にて中大脳動脈領域 の広範な低吸収像を認めた症例の長潜時 SEP で ある。運動麻痺は軽く, 深部知覚・表在知覚と もほほ正常であった。両側刺激にて左右頭皮上 よりの記録に非対称性がみられるものの, 患側 刺激ではほほ正常な波形で, 頭頂部での $\mathrm{N}_{19}$ も存 在していた。

この 2 症例の長潜時 SEP の記録からわかるよ 

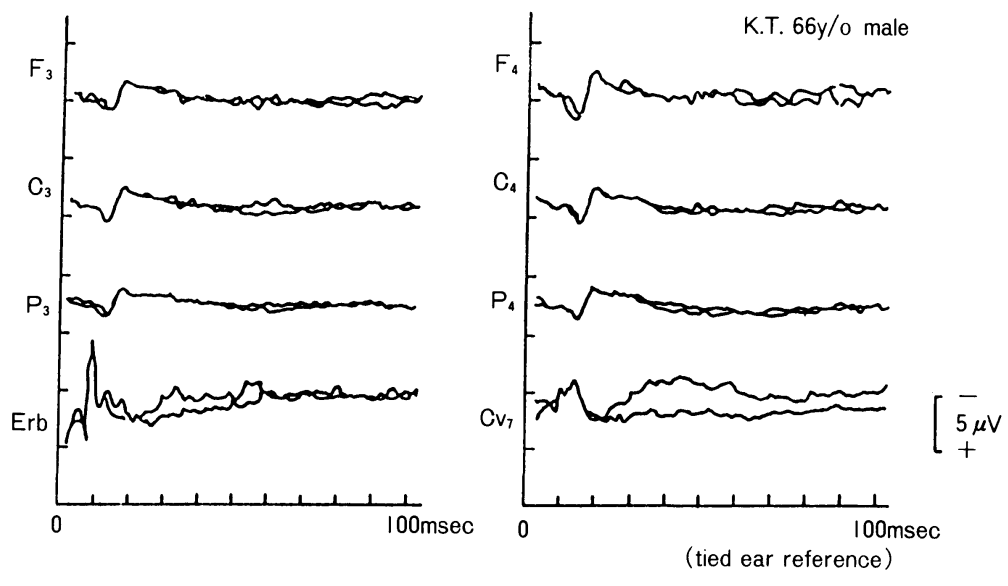

a
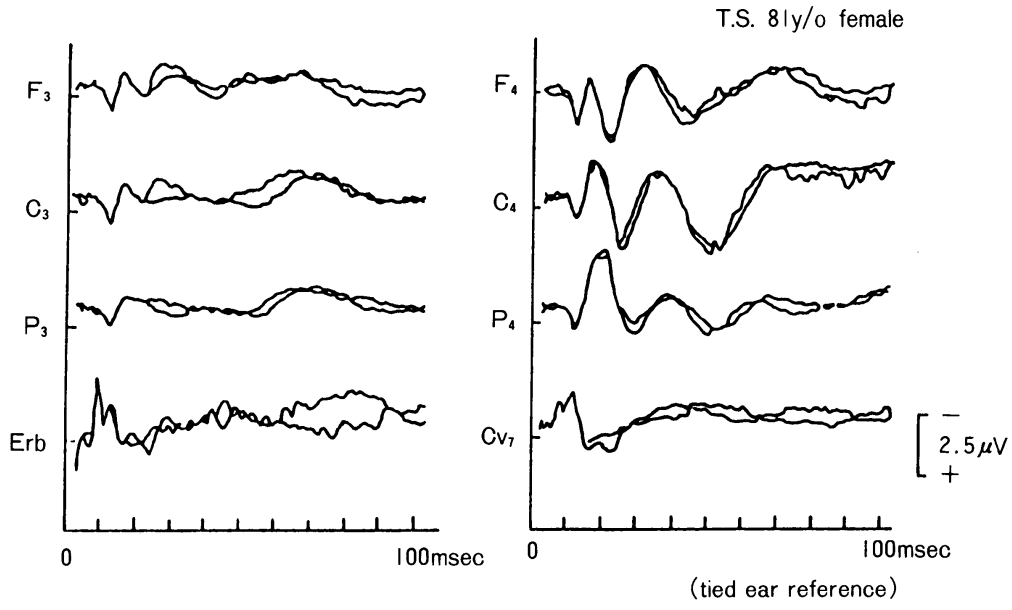

b

図 $7(\mathrm{a}, \mathrm{b})$ 右中大脳動脈領域の脳梗塞の 2 症例の長潜時 SEP

(a) (b)いずれも左上肢刺激による 8 チャンネル同時記録波形である.

(a) では対側頭皮上 $\mathrm{F}_{4} ， \mathrm{C}_{4}, \mathrm{P}_{4}$ から最初の陽性波に続く陰性波しか記録で きていないが，(b)では同部より正常に近い 3 つの陰性波が得られている.

うに, CT 上ほほ同じ所見を示すものでも, 長潜 時 SEP では明らかな違いがみられ，それは感覚 障害とよく相関することがわかる. SEP の機能 評価としての有効性が期待されるわけで, 今後, 経時的に記録することにより予後判定に役立つ 可能性があると思われる。

\section{(3)その他}

末梢神経, 大脳半球障害のほか, 脊髄, 脳幹 部, 視床など多くの病変にたいしての SEP が報 告されている。また，多発性硬化症については， 以前より多くの報告がみられるが，今回は省略 する. 


\section{おわりに}

従来より行われて普遍的な検查となっている 筋電図・神経伝導検査から，今日のトピックス である体性感覚誘発電位に至るまでの神経系の 電気生理学的検査について概説した。この他に も特に麻酔科領域でも盛んに行われている術中 モニタリングなど最近の電気生理学的検査の進 歩はめざましい.これらの検査はあくまで補助 診断であり，結果を過信することは危険である が，貴重な情報をもたらす場合も多く，メディ カルエレクトロニクスの進歩とあいまって, 今 後の臨床応用が更に期待されている.

本稿が多少なりとも本学会の先生方の, この 方面に関する知識の整理に役立てば幸いである。

発表の機会をお与えいただいた，山本道雄会 長および司会の本松研一県立宮崎病院々長に深 謝いたします。

\section{参考文献}

1) 千野直一：臨床筋電図・電気診断学入門 (第 2 版). 医学 書院, 東京, 1981

2) Kimura J : Electrodiagnosis in Diseases of Nerve and Muscle. FA Davis Co, Philadelphia, 1983

3 ) 木村彰男 : 生理機能計側一筋電図および電気生理学的検 查. 理学療法と作業療法 $21: 674 \sim 678,1987$

4 ）木村彰男：上肢知覚神経伝導検査の基本的問題に関する 臨床的研究. リハビリ医学 $21: 85 \sim 93,1984$

5 ) 木村彰男：体性感覚誘発電位. 総合リ八 $14: 5 \sim 11$, 1986

6) Yamada T, Machida M, Tippin J : Somatosensory Evoked Potentials. in Evoked Potential Testing: Clinical Application. Owen JM, Davis H (eds). Grune \& Stratton, Inc, Orlando, Florida, 1984, pp. $109 \sim 158$

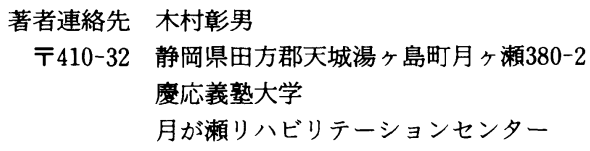

